\title{
Stachybotriaceae on Cucurbits Demystified: Genetic Diversity and Pathogenicity of Ink Spot Pathogens
}

\author{
Gabriel Rennberger ${ }^{\dagger}$ and Anthony P. Keinath \\ Clemson University, Department of Plant and Environmental Sciences, Coastal Research and Education Center, Charleston, SC \\ 29414, U.S.A.
}

\begin{abstract}
Recently, the incidence of Myrothecium leaf spot, a foliar disease of watermelon, has increased in South Carolina. However, the identity of the fungal species responsible for outbreaks of this disease has not been determined. Sequence data from four partial gene regions were used to conduct Bayesian inference in order to identify 95 isolates of Stachybotriaceae. Isolates were collected in South Carolina between July 2015 and May 2018. In total, six species of Stachybotriaceae were identified on watermelon and two other cucurbits: Albifimbria verrucaria, Gregatothecium humicola, Paramyrothecium foliicola, P. humicola, Xenomyrothecium tongaense, and Xepicula leucotricha. Two species, G. humicola and $P$. foliicola, were the predominant species found. Within these two species, genetic differences within small spatial scales were detected. Five species (all except Xenomyrothecium tongaense) were tested in experiments to determine their pathogenicity and relative virulence on three
\end{abstract}

Abstract

hosts grown in rotation in South Carolina. Southern pea plants were less susceptible than watermelon and tomato plants, which were equally susceptible. This constitutes the first reliable report of pathogenicity of any of the five tested species of Stachybotriaceae on these three vegetable crops. Another important finding was that none of the isolates were identified as $P$. roridum, the species considered to be the only causal agent of Myrothecium leaf spot on cucurbits. We propose the common name "ink spot" for the foliar phase of diseases caused by genera within the family Stachybotriaceae. This name is descriptive and likely to be accepted by growers. To prevent further loss incurred by ink spot, watermelon and tomato crops should be monitored for this disease.

Keywords: fungi, pathogen diversity, vegetables

Myrothecium leaf spot on cucurbits is a disease most likely caused by several species in the species complex Myrothecium sensu lato (Bruton and Fish 2017; Lombard et al. 2016). The disease can affect cucurbit foliage, crowns, stems, and fruit. On fruit, it is referred to as crater rot due to the sunken lesions. Symptoms on leaves are round to irregular-shaped lesions with tan centers and brown margins surrounded by a yellow halo. Concentric rings in lesions can be observed frequently. Abundant sporodochia with typical olivaceousgreen to black spore masses are present in lesions on all plant parts (Fig. 1). The pathogen is a common soil inhabitant but there is no specific information about its mode of overwintering (Bruton and Fish 2017). The disease was first reported on Mexican cantaloupe that was intercepted at the Texas border in 1950. Subsequently, the first report in the United States was from the Rio Grande Valley of Texas in 1961 (McLean and Sleeth 1961). Myrothecium leaf spot was since reported in Georgia and Oklahoma in the United States (Bruton and Fish 2012; Seebold et al. 2005). Both reports relied on morphological characteristics for identification and assigned the name Myrothecium roridum to the fungi that were recovered from watermelon leaves.

In a recent survey of foliar pathogens of watermelon (Citrullus lanatus) in South Carolina, 5,999 leaves from 60 commercial fields were examined over the course of four seasons between spring

${ }^{\dagger}$ Corresponding author: G. Rennberger; grennbe@clemson.edu

Technical Contribution number 6807, Clemson University Experiment Station.

Funding: This material is based upon work that is supported, in part, by the United States Department of Agriculture (USDA) National Institute of Food and Agriculture under project number SC-1700536 and the USDA Agricultural Marketing Service under prime grant agreement number 15-SCBGPSC-0013.

The author(s) declare no conflict of interest.

Accepted for publication 6 March 2020.

() 2020 The American Phytopathological Society
2015 and fall 2017. Myrothecium sensu lato was estimated to occur on 26 and $21 \%$ of leaves with foliar lesions in the fall 2017 and fall 2016 seasons, respectively. It also occurred at low levels in spring 2016. That study was the first identification of Myrothecium leaf spot on watermelon in South Carolina (Rennberger et al. 2018).

There are reports of both $M$. roridum and $M$. verrucaria on southern pea (Vigna unguiculata) and of M. roridum on tomato (Solanum lycopersicum) (Farr and Rossman 2018). These two crops are important rotation crops with watermelon in South Carolina (Rennberger et al. 2019). We found 11 reports of species that are on or include cucurbits. The majority of these diseases occur on melon (Cucumis melo) and watermelon but leaf spot diseases caused by members of this group of fungi also occur on other cucurbits (Ali et al. 1988; Cabral et al. 2009; Chen et al. 2018; Yang and Jong 1995). Recently, Matić et al. (2019) identified four species of the family Stachybotriaceae as causal agents of leaf spots on various host plants in Italy, including Paramyrothecium roridum and Albifimbria verrucaria.

The taxonomic rearrangement of the Stachybotriaceae family by Lombard et al. (2016) reduced the genus Myrothecium to only two species, which are characterized by the production of conidia $<5 \mu \mathrm{m}$ in length without mucoid appendages, in slimy, olivaceous to dark-green masses that are "surrounded by a setose fringe" (Lombard et al. 2016). The two species remaining in the genus Myrothecium are $M$. inundatum, the type species for the genus, and $M$. simplex. All but one of the Myrothecium spp. isolates analyzed by Lombard et al. (2016) were originally recovered from decaying agarics. The remaining isolate was obtained from leaf litter. As concluded by Lombard et al. (2016), these findings put the relevance of the genus Myrothecium as plant pathogens into question, and it appears that they are mainly mycoparasites.

In all, 9 of the 13 new Myrothecium-like genera described by Lombard et al. (2016) are monotypic (i.e., contain only one species). Four of these, including Xenomyrothecium tongaense (= M. tongaense), previously were members of the genus Myrothecium. The remaining five monotypic genera, which include Gregatothecium humicola, were established for distinct phylogenetic lineages with specific morphological characteristics (Lombard et al. 2016). Well-known, former Myrothecium spp. that were placed in newly introduced 
genera are $P$. roridum $(=M$. roridum $)$ and $A$. verrucaria $(=M$. verrucaria). Species formerly known as M. leucotricha and $M$. indicum clustered together in a well-supported clade and were synonymized under the already existing taxon name Xepicula leucotricha (Lombard et al. 2016, Nag Raj 1993). Within the established genus Paramyrothecium, the species names $P$. foliicola and $P$. humicola were introduced for two highly supported clades closely related to $P$. roridum (Lombard et al. 2016).

The occurrence of Myrothecium sensu lato in commercial watermelon fields in South Carolina and the severity of the symptoms caused by it has increased in recent years. However, it is unknown what factors caused this increase or if these symptoms lead to yield loss. In order to determine whether the underlying cause is the emergence of a new pathogenic species, it is necessary to correctly identify the species causing Myrothecium leaf spot of watermelon in South Carolina (Rennberger et al. 2018). In addition, Myrothecium sensu lato has been reported to cause leaf spot diseases on tomato and southern pea, which are commonly grown in rotation with cucurbits in South Carolina. The role of crop rotation in the recent increase of findings of Myrothecium sensu lato in watermelon fields in the state is unknown. It is also unknown whether the population of Myrothecium sensu lato present in South Carolina is pathogenic to tomato and southern pea.

The objectives of this study were to (i) identify the fungal species recovered from watermelon and other cucurbits with symptoms of Myrothecium leaf spot observed in four seasons in South Carolina, (ii) characterize the genetic variability within our isolate collection, and (iii) determine the pathogenicity and virulence of the identified species on watermelon, tomato, and southern pea.

\section{Materials and Methods}

Isolate collection. Isolates were obtained from symptomatic leaves collected in 11 commercial watermelon fields from eight growers in four counties in South Carolina in July 2015, June and September 2016, September 2017, and May 2018. In addition, one isolate each was recovered from cassabanana (Sicana odorifera) and cucumber (C. sativus) plants in research plots in Charleston, SC, in October 2016 and May 2017, respectively. The majority of isolates $(n=78)$ were collected in four fields on two farms in Beaufort County in September 2017 based on a sampling scheme described previously (Rennberger et al. 2018). Briefly, a stratified two-stage cluster sampling design was used in which preselected counties represented strata, randomly selected growers represented the first level of clustering, and fields randomly selected from all fields of a chosen grower represented the second level of clustering. Included counties were chosen based on their watermelon acreage (Rennberger et al. 2018). All fields were sampled within 1 week of the start or end of harvest. Within each field, samples were taken along four perpendicular transects, each consisting of five sampling points spaced $10 \mathrm{~m}$ from one another. Consequently, the sampled square area within a field encompassed an area of 2,500 $\mathrm{m}^{2}(0.62$ acres). At each sampling point, five leaves with spots were collected. Borders of fields were avoided whenever possible. For isolates collected from the four fields in Beaufort county in fall 2017, the location of origin at the sampling point and leaf scale were recorded.

Leaf pieces were cut from lesions on symptomatic leaves, surface disinfested in $0.825 \%$ sodium hypochlorite for $60 \mathrm{~s}$, rinsed in autoclaved deionized water, and placed onto quarter-strength potato dextrose agar (QPDA) amended with chloramphenicol at $0.1 \mathrm{~g} /$ liter, streptomycin at $0.1 \mathrm{~g} /$ liter, and mefenoxam at $45.3 \mu \mathrm{l} /$ liter (Ridomil Gold SL; Syngenta, Greensboro, NC, U.S.A.) for pathogen recovery (Keinath 2008). In total, 95 single-conidium isolates originating from five counties in South Carolina were obtained between July 2015 and May 2018. The number of leaf samples examined was 2,099 in spring 2015, 2,400 in spring 2016, 1,100 in fall 2016, and 400 in fall 2017. All isolates were stored at $-8^{\circ} \mathrm{C}$ on dried filter paper until further use (Table 1).

Morphological characterization. Appearance of mycelium and presence of pigments that diffused into the medium of all isolates was examined. The size and shape of 10 conidia of the isolates used in the pathogenicity tests, as well as the single isolate of $X$. tongaense, were measured with a stage micrometer using a Zeiss Axio Imager.A1 microscope at $\times 1,000$ magnification. To confirm presence of funnel-shaped appendages, conidia of $A$. verrucaria were stained with safranin O (J. T. Baker Chemical Co., Phillipsburg, NJ, U.S.A.) in a $10 \%$ ammonia solution (Tulloch 1972).

Pathogenicity tests. One representative isolate of A. verrucaria, $P$. foliicola, $P$. humicola, and X. leucotricha and two isolates of $G$. humicola were used for pathogenicity tests (Matić et al. 2019). Two isolates of $G$. humicola were included because it was the most common species. The single isolate of $X$. tongaense identified in this study was not included in the pathogenicity tests. Seeding of southern pea cultivar Quickpick Pinkeye, tomato cultivar BHN602, and watermelon cultivar Tri-X-313 was staggered to obtain plants of similar sizes. Watermelon was seeded 14 days after tomato, and southern pea was seeded 11 days after watermelon. Approximately 7 days after southern pea were seeded, two plants for each host were transplanted into 10.2-cm-wide square plastic pots and kept on greenhouse benches for 13 days until they were inoculated. At the time of inoculation, tomato, watermelon, and southern pea plants were 45, 31, and 20 days old, respectively.

Fungi were grown on QPDA for 3 to 4 weeks. Culture plates were flooded twice with $7 \mathrm{ml}$ of sterile deionized water and scraped with sterile microscope slides. Conidia densities were counted using a hemocytometer and were adjusted to $1 \times 10^{6}$ conidia $/ \mathrm{ml}$ for the first test and $2 \times 10^{6}$ conidia/ml for all subsequent tests. Handheld spray bottles were used to apply inoculum suspensions to the entire surface area of plants until run-off. One pot of each host-fungus combination was then transferred into each of five humidity chambers in the greenhouse and incubated for 4 days at $\geq 95 \%$ relative humidity and $30 \pm 5^{\circ} \mathrm{C}$. The experimental design was a randomized complete block design with five blocks and one replication per block. Each humidity chamber represented an experimental block. Control plants of each host were sprayed with deionized water and added to each humidity chamber. Subsequently, pots were removed from the chambers and placed onto greenhouse benches for 7 days. The randomization in the chambers was maintained on the greenhouse benches. After this, the numbers of affected plant parts and total lesions per plant were counted. Disease incidence was recorded as presence or absence of symptoms on each plant in a pot, and disease severity was rated as the percentage of affected leaf area per plant using a scale of 0 to $100 \%$ in $5 \%$ increments, plus $1 \%$ for minor symptoms. Two pieces of leaf tissue from each symptomatic plant were cultured to recover the pathogens, as described previously. After 4 days of incubation at $24 \pm 1^{\circ} \mathrm{C}$ with a 12 -h light cycle, culture plates were examined, and ratings for plants from which no pathogen was recovered were excluded from the data set. For confirmation of identity, two isolates from each treatment were saved and used to assess colony color and mycelium morphology. In addition, size and shape of conidia were determined microscopically at $\times 1,000$ magnification. Pathogenicity tests were done four times.

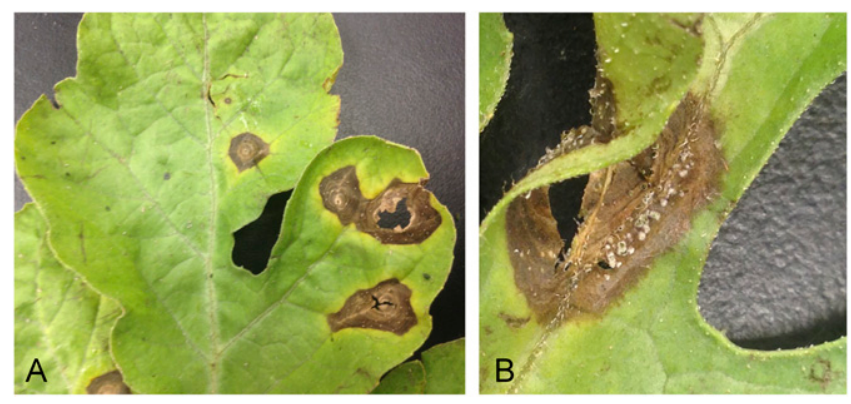

Fig. 1. Typical symptoms of ink spot on watermelon leaves collected from commercial fields in September 2016. A, Round to irregular-shaped lesions with concentric rings, tan centers, and brown margins surrounded by a yellow halo. Lesions tend to crack, and the centers of large lesions may disintegrate. B, Characteristic olivaceous-green to black spore masses on sporodochia developing on ink spot leaf lesion. 
DNA extraction and amplification. Fungal mycelium was grown in $100 \mathrm{ml}$ of potato dextrose broth for 14 days. Extractions of genomic DNA were done using a DNeasy Plant Mini Kit (Qiagen, Redwood City, CA, U.S.A.). Clay beads, two scoops of fine sand, and $100 \mathrm{mg}$ of wet mycelium were added into $2-\mathrm{ml}$ round-bottom tubes. Following this, $400 \mu \mathrm{l}$ of lysis buffer was added and the tissue was lysed for two cycles of $20 \mathrm{~s}$ in a bead beater (FastPrep-24; M.P. Biomedicals, Irvine, CA, U.S.A.), after which $4 \mu \mathrm{l}$ of RNAse A was added and samples were incubated at $65^{\circ} \mathrm{C}$ for $10 \mathrm{~min}$. From this point on, extractions were done according to the manufacturer's instructions. DNA concentrations were adjusted to $10 \mathrm{ng} / \mu \mathrm{l}$ for use in PCR. Partial sequences were amplified for calmodulin $(C A L)$ with primers CAL-288F and CAL2Rd (Groenewald et al. 2013), the internal transcribed spacer region (ITS) with primers ITS4 and ITS5 (White et al. 1990), RNA polymerase II second largest subunit $(R P B 2)$ with primers RPB2-5F2 and RPB2-7cR (O'Donnell et al. 2007), and $\beta$-tubulin (TUB2) with primers Bt2a and Bt2b (Glass and Donaldson 1995). Lombard et al. (2016) found CAL, TUB2, and $R P B 2$ to provide the best statistical support in resolving genera and species in the family Stachybotriaceae. Although ITS was shown to provide the least resolution at the generic and species level, it was included because it is the standard fungal barcode (Lombard et al. 2016; Schoch et al. 2012). All primers were diluted to a concentration of $10 \mathrm{mM}$ for use in PCR. All PCR assays were run on a PTC-200 Peltier thermal cycler (MJ Research Inc., Watertown, MA, U.S.A.) in a total volume of $30 \mu \mathrm{l}$. For $C A L$, reactions consisted of $6 \mu \mathrm{l}$ of $5 \times$ green GoTaq buffer, $3 \mu$ l of dNTPs, $1.5 \mu l$ of each primer, $0.18 \mu \mathrm{l}$ of GoTaq, and $2 \mu \mathrm{l}$ of DNA template. Thermal cycling was done as described by Carbone and Kohn (1999). For ITS, reactions consisted of $6.1 \mu \mathrm{l}$ of $5 \times$ green GoTaq buffer (Promega Corp., Madison, WI, U.S.A.), $1.22 \mu \mathrm{l}$ of dNTPs (Applied Biosystems, Foster City, CA, U.S.A.), $1.22 \mu$ l of each primer, $0.305 \mu$ l of GoTaq (Promega Corp.), and $2 \mu \mathrm{l}$ of DNA template. Thermal cycling was initiated by denaturing at $94^{\circ} \mathrm{C}$ for $5 \mathrm{~min}$, which was followed by 35 cycles of $94^{\circ} \mathrm{C}$ for $1 \mathrm{~min}, 55^{\circ} \mathrm{C}$ for $1 \mathrm{~min}$, and $72^{\circ} \mathrm{C}$ for $1 \mathrm{~min}$. The PCR was completed by a final step of $72^{\circ} \mathrm{C}$ for $10 \mathrm{~min}$ and cooling the reaction to $4^{\circ} \mathrm{C}$ until further use. For $R P B 2$, reactions consisted of $6 \mu l$ of $5 \times$ green GoTaq buffer, $3 \mu l$ of dNTPs, $2.4 \mu l$ of each primer, $0.18 \mu \mathrm{l}$ of GoTaq, and $2 \mu \mathrm{l}$ of DNA template. A touchdown PCR protocol was developed for the amplification of $R P B 2$. Thermal cycling was initiated by denaturing at $94^{\circ} \mathrm{C}$ for $90 \mathrm{~s}$. Subsequently, 10 cycles consisting of $94^{\circ} \mathrm{C}$ for $30 \mathrm{~s}$, an annealing temperature dropping by $0.4^{\circ} \mathrm{C}$ in each cycle from $60^{\circ} \mathrm{C}$ to $56.4^{\circ} \mathrm{C}$ for $90 \mathrm{~s}$, and $68^{\circ} \mathrm{C}$ for $2 \mathrm{~min}$ were run. This was followed by 17 cycles of $94^{\circ} \mathrm{C}$ for $30 \mathrm{~s}, 56^{\circ} \mathrm{C}$ for $90 \mathrm{~s}$, and $68^{\circ} \mathrm{C}$ for $2 \mathrm{~min}$. The PCR was completed by a final step of $72{ }^{\circ} \mathrm{C}$ for 5 min and cooling the reaction to $4^{\circ} \mathrm{C}$ until further use. For $T U B 2$, reactions consisted of $6 \mu \mathrm{l}$ of $5 \times$ green GoTaq buffer, $3 \mu$ l of dNTPs, $0.6 \mu$ l of each primer, $0.18 \mu$ l of GoTaq, and $2 \mu \mathrm{l}$ of DNA template. Thermal cycling was initiated by denaturing at $94^{\circ} \mathrm{C}$ for $2 \mathrm{~min}$, which was followed by 32 cycles of $94^{\circ} \mathrm{C}$ for $1 \mathrm{~min}, 58^{\circ} \mathrm{C}$ for $1 \mathrm{~min}$, and $72^{\circ} \mathrm{C}$ for $1 \mathrm{~min}$ (Glass and Donaldson 1995). The PCR was completed by a final step of $72^{\circ} \mathrm{C}$ for $5 \mathrm{~min}$ and cooling the reaction to $4^{\circ} \mathrm{C}$ until further use. Afterward, PCR products were stored at $4^{\circ} \mathrm{C}$ until further use.

Molecular analyses. All amplicons were sequenced in both directions in order to validate sequences. All sequencing reactions were carried out by Functional Biosciences, Inc. (Madison, WI, U.S.A.) using Sanger sequencing with Big Dye V3.1 and run on an ABI $3730 x 1$ instrument. For each isolate, consensus sequences for the four loci were assembled in Geneious (v. 10.2.4), and additional sequences for Myrothecium sensu lato from Lombard et al. (2016) were obtained from GenBank. Alignments for each locus were prepared with MAFFT (v. 7.388) in Geneious and adjusted manually when necessary (Katoh and Standley 2013). All sequences generated for this study were deposited in GenBank under accession numbers MN593626 to MN593720 (CAL), MN227386 to MN227480 (ITS), MN397956 to MN398050 (RPB2), and MN398051 to MN398145 (TUB2). The alignments of the four loci were concatenated in Geneious.

Bayesian inference (BI) was used for phylogenetic analyses of alignments and concatenated alignments. The most suitable nucleotide substitution model for each dataset was chosen with jModelTest 2, which was run through the CIPRES website (Miller et al. 2010). The models chosen were based on the Akaike information criterion corrected for small sample sizes and were incorporated in the analysis with BI (Darriba et al. 2012). Models that are not available in MrBayes were replaced by the closest over-parameterized model (Huelsenbeck and Rannala 2004; Lecocq et al. 2013). The selected models were Jukes Cantor for TUB2; generalized time-reversible model with $\gamma$ distribution for $C A L$, ITS, and $R P B 2$; and generalized time-reversible model with invariable sites and $\gamma$ distribution for the concatenated alignment of all four gene regions. MrBayes (v.3.2.6) was employed for BI analyses on the CIPRES website to generate phylogenetic trees under optimal criteria for each gene region. A Markov Chain Monte Carlo (MCMC) algorithm starting from a random tree topology with four chains running in parallel was utilized with a heating parameter of 0.3 until the average standard deviations of split differences were below 0.01 . The number of generations was set to $2 \times 10^{8}$. Trees were saved every 1,000 generations and $25 \%$ of the trees was discarded as a burn-in phase. Posterior probabilities

Table 1. Number of isolates per species of Stachybotriaceae recovered from cucurbits in South Carolina in 2015 to 2018

\begin{tabular}{|c|c|c|c|c|c|c|c|c|c|c|c|c|c|c|}
\hline \multirow[b]{3}{*}{ Species } & \multirow[b]{3}{*}{ Month, year } & \multicolumn{12}{|c|}{ Counties $^{x}$} & \multirow[b]{3}{*}{ Total } \\
\hline & & \multicolumn{5}{|c|}{ Beaufort } & \multicolumn{2}{|c|}{ Bamberg } & \multirow[b]{2}{*}{ Barn } & \multirow[b]{2}{*}{ Char } & \multicolumn{3}{|c|}{ Colleton } & \\
\hline & & $\overline{\mathrm{A1}}$ & A2 & B1 & B2 & $\overline{\text { B3 }}$ & $\overline{\mathrm{C1}}$ & $\overline{\mathrm{C} 2}$ & & & $\overline{\text { D1 }}$ & D2 & $\overline{\text { D3 }}$ & \\
\hline$\overline{\text { Albifimbria verrucaria }}$ & September 2017 & 1 & 2 & 0 & 0 & 0 & 0 & 0 & 0 & 0 & 0 & 0 & 0 & 3 \\
\hline Gregatothecium humicola & September 2017 & 27 & 1 & 3 & 20 & 0 & 0 & 0 & 0 & 0 & 0 & 0 & 0 & 51 \\
\hline \multirow[t]{4}{*}{ Paramyrothecium foliicola } & July 2015 & 0 & 0 & 0 & 0 & 0 & 0 & 0 & 0 & 0 & 1 & 0 & 0 & 1 \\
\hline & September 2016 & 0 & 0 & 0 & 0 & 5 & 0 & 0 & 0 & 0 & 0 & 0 & 0 & 5 \\
\hline & October 2016 & 0 & 0 & 0 & 0 & 0 & 0 & 1 & 0 & 0 & 0 & 0 & 0 & 1 \\
\hline & September 2017 & 0 & 0 & 0 & 23 & 0 & 0 & 0 & 0 & 0 & 0 & 0 & 0 & 23 \\
\hline Paramyrothecium sp. & June 2016 & 0 & 0 & 0 & 0 & 0 & 1 & 0 & 0 & 0 & 0 & 1 & 1 & 3 \\
\hline \multirow[t]{2}{*}{ P. humicola } & June 2016 & 0 & 0 & 0 & 0 & 0 & 0 & 0 & 0 & 0 & 0 & 1 & 0 & 1 \\
\hline & May 2017 & 0 & 0 & 0 & 0 & 0 & 0 & 0 & 0 & $1^{\mathrm{y}}$ & 0 & 0 & 0 & 1 \\
\hline \multirow[t]{4}{*}{ Xepicula leucotricha } & June 2016 & 0 & 0 & 0 & 0 & 0 & 0 & 0 & 0 & 0 & 0 & 2 & 0 & 2 \\
\hline & September 2016 & 0 & 0 & 0 & 0 & 1 & 0 & 0 & 0 & 0 & 0 & 0 & 0 & 1 \\
\hline & October 2016 & 0 & 0 & 0 & 0 & 0 & 0 & 0 & 0 & $1^{\mathrm{z}}$ & 0 & 0 & 0 & 1 \\
\hline & May 2018 & 0 & 0 & 0 & 0 & 0 & 0 & 0 & 1 & 0 & 0 & 0 & 0 & 1 \\
\hline Xenomyrothecium tongaense & September 2017 & 1 & 0 & 0 & 0 & 0 & 0 & 0 & 0 & 0 & 0 & 0 & 0 & 1 \\
\hline Total & $\ldots$ & 29 & 3 & 3 & 43 & 6 & 1 & 1 & 1 & 2 & 1 & 4 & 1 & 95 \\
\hline
\end{tabular}

$\mathrm{x}$ A1 to D3 designate different farms (letters) and fields (numbers) in the same county. Barn $=$ Barnwell and Char $=$ Charleston.

${ }^{\mathrm{y}}$ Isolate was recovered from a symptomatic cucumber (Cucumis sativus) leaf in a research plot in Charleston, SC.

${ }^{\mathrm{z}}$ Isolate was recovered from a symptomatic leaf of Sicana odorifera in a research plot in Charleston, SC. All other isolates were recovered from watermelon. 
(PP) were calculated from the remaining trees and consensus trees were computed in MrBayes (v.3.2.6) using the 50\% majority rule. The four gene regions were analyzed separately and combined, and five analyses were conducted independently for each gene region and the combined data set (Lecocq et al. 2013). The potential scale reduction factor (PSRF) was used to validate convergence of MCMC.
The PSRF approached a value of 1.000 for all branch and node parameters, indicating convergence (Brooks and Gelman 1998).

The genetic diversity within species was estimated by calculating haplotype diversity $(h)$, nucleotide diversity $(\pi)$, number of haplotypes (k), and number of polymorphic sites (PS) for each gene. $X$. tongaense was excluded from this analysis because it was

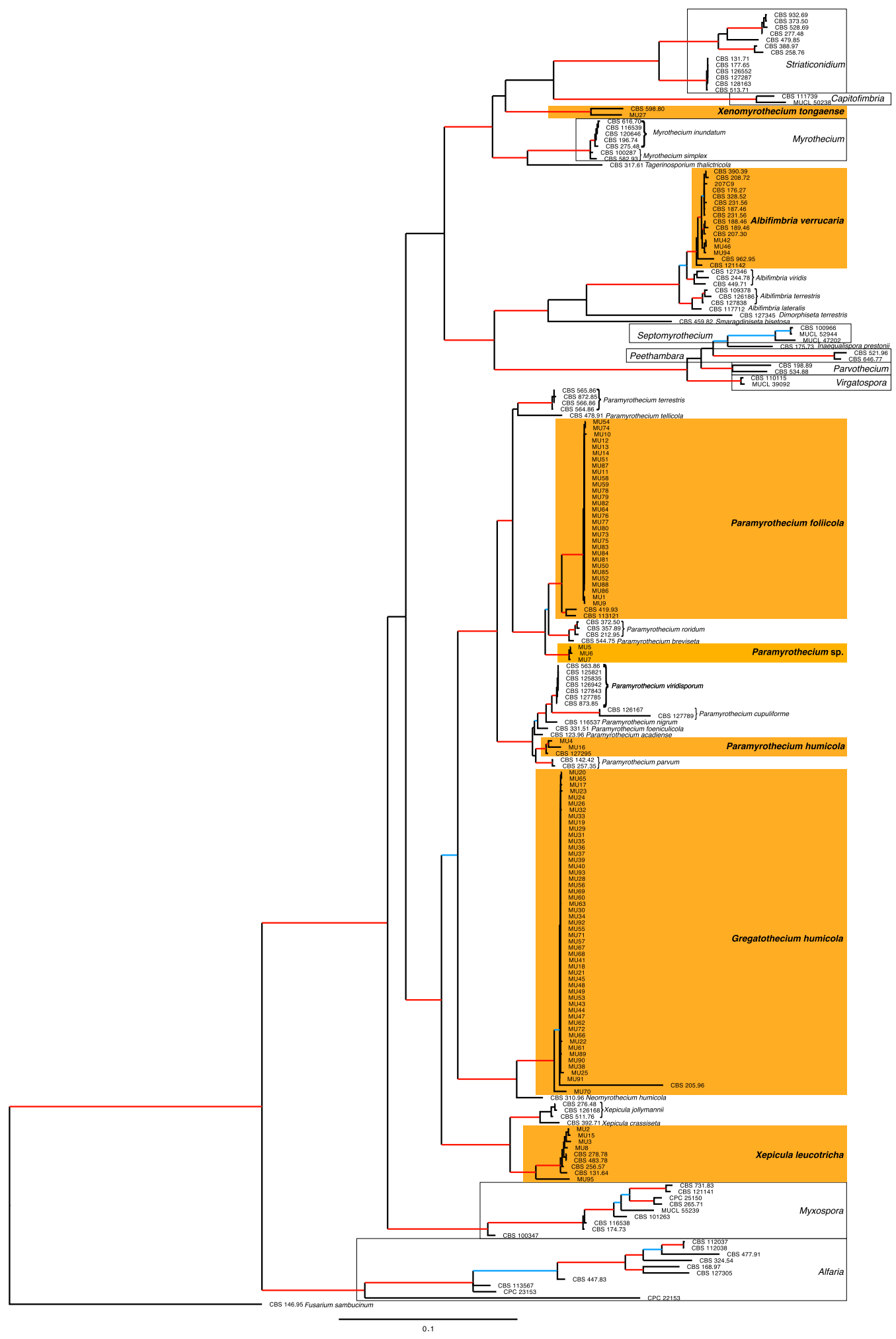

Fig. 2. Multilocus consensus tree based on the combined sequence alignment of calmodulin, internal transcribed spacer, $\beta$-tubulin, and RNA polymerase II second largest subunit. The tree was computed with Bayesian inference. Isolates collected for this study are named MU1 to MU95. The complete data set of Myrothecium-like fungi from Lombard et al. (2016) was included as a reference. The scale bar indicates 0.1 expected changes per site. The tree is rooted in Fusarium sambucinum (CBS146.95). In the online version, branches with posterior probabilities of 1.0 are in red and branches with posterior probabilities of $\geq 0.95$ are in blue. 
represented by only one isolate in the collection (Table 1). DnaSP (v.5) was used to estimate these four measures of genetic diversity (Nei and Tajima 1983; Rozas and Rozas 1997).

Statistical analysis. All statistical analyses were computed with PROC GLIMMIX of SAS statistical software (v. 9.4; SAS Institute Inc., Cary, NC, U.S.A.). Incidence data were analyzed with a binomial model, with host, isolate, and host-isolate interaction as fixed effects and experiment and blocks within experiment as random effects. The logit function was used as link function, and model fit was assessed with fit statistics and Pearson residual plots. The SOLUTION option of the MODEL statement was used to back-transform the data, and pairwise comparisons between isolates and hosts were calculated with paired $t$ tests of least squares means using the LSMEANS statement in PROC GLIMMIX. Count data of number of affected plant parts and number of lesions per plant as well as severity ratings were analyzed by fitting the same model with a Poisson distribution and using the log function as the link function in the model. Linear contrasts were specified in the estimate statement to compare fungal species. The same analyses were used subsequently to analyze data sets separately for each host.

\section{Results}

Species identity. Phylogenetic analysis was conducted on the combined sequences of $C A L$, ITS, TUB2, and $R P B 2$. Tree topology and relationships among taxa closely resembled those reported by Lombard et al. (2016). Three isolates (MU42, MU46, and MU94) clustered together with 13 reference strains of $A$. verrucaria with high statistical support $(\mathrm{PP}=1.0)($ Fig. 2). The largest group of isolates in the collection, 51 isolates (MU17 to -26, MU28 to -41, MU43 to -45 , MU47 to -49 , MU53, MU55 to -57 , MU60 to -63 , MU65 to -72 , and MU89 to -93), formed a clade with $G$. humicola reference strain CBS 205.96 (PP $\geq 0.95$ ). The second largest set of 30 isolates (MU1, MU9 to -14, MU50 to -52, MU54, MU58 and 59, MU64, and
MU73 to -88) clustered together with $P$. foliicola reference strains CBS 113121 and CBS 419.93 but formed a separate clade within $P$. foliicola distinct from the reference strains ( $\mathrm{PP}=1.0)$. Two isolates, MU4 and MU16, formed a highly supported $(\mathrm{PP}=1.0)$ clade with $P$. humicola reference strain CBS 127295 and were closely related to $P$. parvum (CBS 142.42 and CBS 257.35). Isolate MU27 was the sole representative that clustered with $X$. tongaense reference strain CBS 598.80 ( $\mathrm{PP}=1.0$ ). Five isolates (MU2, MU3, MU8, MU15, and MU95) formed a clade of high statistical support with $X$. leucotricha reference strains CBS 131.64, CBS 256.57, CBS 278.78, and CBS 483.78 ( $\mathrm{PP}=1.0$ ). MU95, however, was distinct from all other isolates and reference strains $(\mathrm{PP}=1.0)($ Fig. 2). The remaining three isolates (MU5 to MU7) formed a distinct clade most closely related to $P$. breviseta, $P$. foliicola, and $P$. roridum and, therefore, could not be identified to species level. Their membership in the genus Paramyrothecium, however, is well supported $(\mathrm{PP}=1.0)$.

Morphological characteristics. All isolates produced sporodochial conidiomata with olivaceous green to black spore masses and aseptate conidia. A. verrucaria isolates lacked aerial mycelium and exuded a light-cream to orange-colored pigment into the medium (Fig. 3). Conidia were lemon-shaped to fusiform, hyaline, and measured $7.5 \pm 0.5 \mu \mathrm{m}$ in length and $2.3 \pm 0.3 \mu \mathrm{m}$ in width. In addition, conidia had funnel-shaped appendages that were visible when stained as described. These characteristics correspond to the description by Tulloch (1972). G. humicola isolates had white aerial mycelium that became immersed and produced an orange pigment that changed the color of the medium. Conidia were cylindrical to subcylindrical with rounded ends, hyaline, and $6.9 \pm 0.5 \mu \mathrm{m}$ long and 1.93 $\pm 0.2 \mu \mathrm{m}$ wide. $P$. foliicola isolates produced abundant white aerial mycelium but, apart from one isolate that produced a light-orangecolored pigment, did not change the color of the medium. Conidia were cylindrical to subcylindrical with rounded ends, hyaline, and
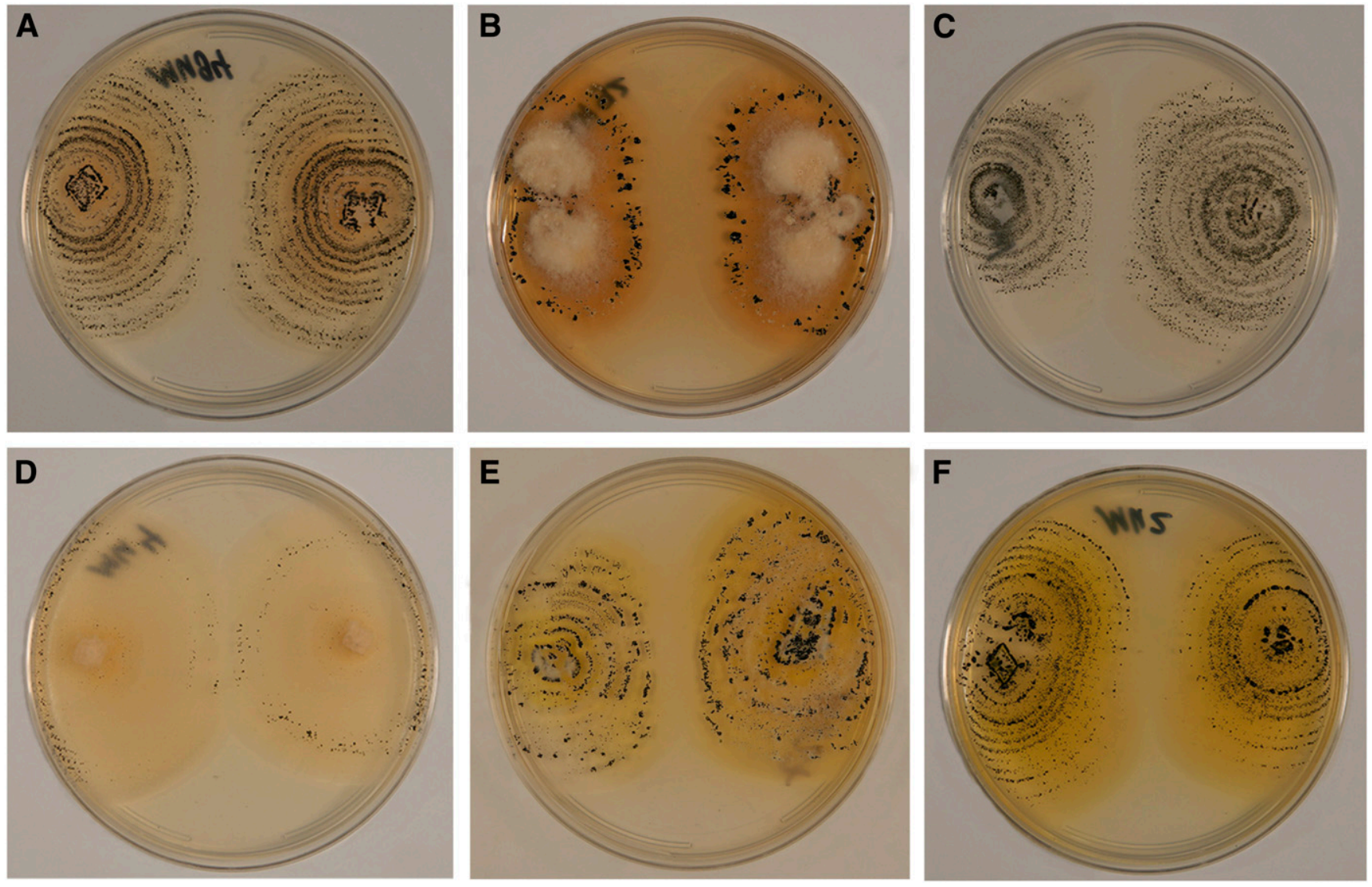

Fig. 3. Culture appearance of six species of Stachybotriaceae recovered from watermelon in commercial fields in South Carolina. A, Albifimbria verrucaria. B, Gregatothecium humicola. C, Paramyrothecium foliicola. D, P. humicola. E, Xenomyrothecium tongaense. F, Xepicula leucotricha. All species produced a pigment that diffused into the agar, except P. foliicola. 
measured $6.3 \pm 0.5 \mu \mathrm{m}$ in length and $1.4 \pm 0.3 \mu \mathrm{m}$ in width. Mycelium of $P$. humicola was mostly immersed, and a light-orangecolored exudate was produced that diffused into the medium. Conidia were cylindrical to subcylindrical with rounded ends, hyaline, and measured $8.9 \pm 0.6 \mu \mathrm{m}$ in length and $2.0 \pm 0.0 \mu \mathrm{m}$ in width. $X$. tongaense had sparse white aerial mycelium that was mostly immersed. It produced a distinct yellow exudate that diffused into the medium. Conidia were cylindrical to subcylindrical with rounded ends, hyaline, and measured $6.4 \pm 0.5 \mu \mathrm{m}$ in length and $2.0 \pm 0.0 \mu \mathrm{m}$ in width. The mycelium of $X$. leucotricha was dense and appressed. Conidia were cylindrical to subcylindrical with rounded ends, hyaline, and $7.3 \pm 0.4 \mu \mathrm{m}$ long and $2.0 \pm 0.0 \mu \mathrm{m}$ wide. The color of $X$. leucotricha on QPDA was light yellow or beige to deep yellow (Fig. 3).

Species diversity. G. humicola and A. verrucaria were found only in September 2017 in Beaufort County (Table 1). G. humicola was recovered from leaves collected in all four fields, while A. verrucaria occurred in only two fields. P. foliicola was found in one field in Colleton County in July 2015, one field each in Bamberg and Beaufort counties in September 2016, and one field in Beaufort county in September 2017. The two isolates of $P$. humicola were recovered from leaf samples collected from a field in Colleton County in June 2016 and from a research plot in Charleston County in May 2017. The three isolates that formed a distinct clade within the genus Paramyrothecium were collected in June 2016 from two fields in Colleton County and a field in neighboring Bamberg County. The single isolate identified as $X$. tongaense was collected in a field in Beaufort County in September 2017. X. leucotricha was found in a field in Colleton County in June 2016, a field in Beaufort County in September 2016, from a research plot in Charleston County in October 2016, and from a field in Barnwell County in May 2018 (Table 1).

A vast majority of the 95 isolates were obtained in September 2017 from four fields in Beaufort County managed by two growers, designated fields A1, A2, B1, and B2. Of the 29 isolates obtained from field A1, 27 were $G$. humicola. The remaining two isolates were identified as A. verrucaria and $X$. tongaense. In two fields (A1 and A2) managed by grower A in Beaufort County, 28 and 3 of the 32 isolates recovered were identified as $G$. humicola and $A$ verrucaria, respectively. Among three fields (B1, B2, and B3) managed by grower B, 23 and 28 of the 52 isolates recovered were identified as $G$. humicola and P. foliicola, respectively. Of the 84 isolates collected from the five fields in Beaufort County, 51 from four fields were identified as $G$. humicola and 28 from two fields were identified as P. foliicola (Table 1).

Genetic diversity within species. Measures of genetic diversity were computed for the five species represented by more than one isolate (Tables 1 and 2). More than one haplotype of $C A L$ and $R P B 2$ was detected in all five species. Two different haplotypes of $C A L$ were found for A. verrucaria, P. foliicola, and P. humicola. For A. verrucaria, these haplotypes were based on only one PS whereas, for $P$. foliicola and $P$. humicola, they were based on 5 and 12 PS, respectively. Among the 51 isolates of $G$. humicola, there were three different haplotypes based on 12 PS and, among the five isolates of $X$. leucotricha, there were four different haplotypes based on 64 PS. We found two different haplotypes for RPB2 for A. verrucaria, $G$. humicola, and $P$. humicola, and four different ones for $P$. foliicola and $X$. leucotricha. The haplotypes for $R P B 2$ were based on 6,3 , 8,7 , and 59 PS for these five species, respectively. The only species that had different haplotypes of ITS was X. leucotricha, for which three different haplotypes based on eight PS of ITS were detected. There were two, three, and three different haplotypes of TUB2 for $A$. verrucaria, $G$. humicola, and $X$. leucotricha, respectively. For A. verrucaria, they were based on only 1 PS but, for G. humicola and $X$. leucotricha, they were based on on 45 and 27 PS, respectively. There was only one haplotype of TUB2 for both $P$. foliicola and $P$. humicola. Due to the low number of isolates of $A$. verrucaria, $P$. humicola, and X. leucotricha, $\pi$ and $h$ can only be compared meaningfully between $G$. humicola and $P$. foliicola. For $C A L$ and RPB2, $P$. foliicola was more genetically diverse than $G$. humicola with regards to both $\pi$ and $h$ but, for TUB2, G. humicola was more genetically diverse than $P$. foliicola.

Genetic differences within the 78 isolates collected in fall 2017 were detected on small spatial scales in three fields (A1, A2, and B2) in Beaufort County, which constitute the majority of our isolate

Table 2. Genetic diversity of five species of Stachybotriaceae

\begin{tabular}{|c|c|c|c|c|c|c|c|}
\hline Species & $n^{\mathbf{u}}$ & MLG $^{v}$ & Locus $^{w}$ & Sites $^{\mathrm{x}}$ & Haplotypes & Nucleotide diversity $(\pi)^{y}$ & Haplotype diversity $(h)^{\mathrm{z}}$ \\
\hline \multirow[t]{4}{*}{ Albifimbria verrucaria } & 3 & 2 & $C A L$ & 1 & 2 & 0.00101 & 0.667 \\
\hline & $\ldots$ & $\ldots$ & ITS & 0 & 1 & 0.00000 & 0.000 \\
\hline & $\ldots$ & $\ldots$ & $R P B 2$ & 6 & 2 & 0.00445 & 0.667 \\
\hline & $\ldots$ & $\ldots$ & TUB2 & 1 & 2 & 0.00207 & 0.667 \\
\hline \multirow[t]{4}{*}{ Gregatothecium humicola } & 51 & 6 & $C A L$ & 12 & 3 & 0.00071 & 0.078 \\
\hline & $\ldots$ & $\ldots$ & ITS & 0 & 1 & 0.00000 & 0.000 \\
\hline & $\ldots$ & $\cdots$ & $R P B 2$ & 3 & 2 & 0.00014 & 0.039 \\
\hline & $\ldots$ & $\ldots$ & $T U B 2$ & 45 & 3 & 0.00591 & 0.078 \\
\hline \multirow[t]{4}{*}{ Paramyrothecium foliicola } & 30 & 5 & $C A L$ & 5 & 2 & 0.00097 & 0.129 \\
\hline & $\ldots$ & $\ldots$ & ITS & 0 & 1 & 0.00000 & 0.000 \\
\hline & $\ldots$ & $\ldots$ & $R P B 2$ & 8 & 4 & 0.00061 & 0.193 \\
\hline & $\ldots$ & $\ldots$ & $T U B 2$ & 0 & 1 & 0.00000 & 0.000 \\
\hline \multirow[t]{4}{*}{ P. humicola } & 2 & 2 & $C A L$ & 12 & 2 & 0.01815 & 1.000 \\
\hline & $\ldots$ & $\ldots$ & ITS & 0 & 1 & 0.00000 & 0.000 \\
\hline & $\ldots$ & $\ldots$ & $R P B 2$ & 7 & 2 & 0.00784 & 1.000 \\
\hline & $\ldots$ & $\ldots$ & $T U B 2$ & 0 & 1 & 0.00000 & 0.000 \\
\hline \multirow{4}{*}{ Xepicula leucotricha } & 5 & 5 & $C A L$ & 64 & 4 & 0.03979 & 0.906 \\
\hline & $\ldots$ & $\ldots$ & ITS & 8 & 3 & 0.00686 & 0.700 \\
\hline & $\ldots$ & $\ldots$ & $R P B 2$ & 59 & 4 & 0.02592 & 0.900 \\
\hline & $\ldots$ & $\ldots$ & $T U B 2$ & 27 & 3 & 0.03529 & 0.700 \\
\hline
\end{tabular}

u Number of isolates identified per species.

$\checkmark$ Multilocus genotypes.

w $C A L=$ calmodulin, ITS $=$ internal transcribed spacer, $T U B 2=\beta$-tubulin, and $R P B 2=$ RNA polymerase II second largest subunit.

x Polymorphic sites.

y Nucleotide diversity was computed in DnaSP (v.5) and is defined as $\pi=k / m$, where $m$ is the total number of nucleotide positions (including monomorphic positions but excluding positions with alignment gaps) and $k$ is defined as the mean number of nucleotide differences: $k=\frac{2}{n(n-1)} \sum d_{i j}$, where $n$ is the number of sequences and $d_{i j}$ is the number of nucleotide differences between sequences $i$ and $j$ (Rozas 2009).

z Haplotype diversity was computed in DnaSP (v.5) and is defined as the probability that two randomly chosen sequences are different: $h=\frac{n}{n-1}\left(1-\sum_{i=1}^{h} p_{i}^{2}\right)$, where $n$ is the number of sequences, $h$ is the number of haplotypes, and $p_{i}$ is the relative frequency of haplotype $i$ (Rozas 2009). 
collection (Tables 1 and 2). Based on the sequences of the four gene regions that were examined, the majority of $G$. humicola isolates appeared clonal. Only five isolates differed from the predominant multilocus genotype (MLG) at sites on either $C A L, T U B 2$, or $R P B 2$. In all, 3 of the 27 isolates of $G$. humicola collected from field A1 originated from three lesions on the same leaf. These three isolates represented two haplotypes for $C A L$ and two for $R P B 2$. In addition, there were two haplotypes for $T U B 2$ within two adjacent sampling points approximately $10 \mathrm{~m}$ apart. There were four different MLG in field A1 and three different ones in field B2. The predominant clonal MLG in field A1 represented 24 of 27 isolates and, in field B2, 18 of 20 isolates. It was the only MLG found in field A2 and $\mathrm{B} 1$. In field $\mathrm{A} 2$, the two isolates of $A$. verrucaria separated into different haplotypes for all gene regions except for ITS. For $P$. foliicola, there were two MLG in fields B2 and B3. In field B2, 22 of the 23 isolates and, in field B3, 4 of the 5 isolates were the predominant MLG. Each isolate of X. leucotricha represented a different MLG.

At two sampling points in field B2, both species found in the field (G. humicola and P. foliicola) were recovered from separate leaves collected at the same sampling point. At one sampling point, we identified two different $C A L$ haplotypes of $G$. humicola. Additionally, two different haplotypes of G. humicola were identified for TUB2 within two adjacent sampling points in field B2. Of the 23 isolates of $P$. foliicola collected in field B2, 22 belonged to the same haplotype for all four gene regions that were analyzed. However, two isolates of $P$. foliicola with different $R P B 2$ haplotypes were recovered from the same leaf, which was the only genetic difference for this species detected in that field.

Pathogenicity. High temperatures of $35^{\circ} \mathrm{C}$ in the greenhouse during one of the pathogenicity tests did not influence the development of symptoms compared with the other tests, which were conducted in cooler temperatures of approximately $25^{\circ} \mathrm{C}$. Culture characteristics and morphology of conidia confirmed the identity of all representative isolates recovered from symptomatic plants. There was no significant host-isolate interaction for disease incidence $(P=0.29)$. In the combined analysis with all hosts, there was no difference in disease incidence among the tested isolates $(P>0.09)$ and species $(P>$ $0.13)$ but there was a highly significant $(P<0.0001)$ difference in disease incidence among hosts. Significantly fewer $(P<0.0001)$ southern pea plants were symptomatic than tomato or watermelon plants. Tomato (60.4\% disease incidence) had the highest disease incidence but incidence was not significantly $(P>0.36)$ different from watermelon $(54.1 \%)$. When incidence was analyzed separately by host, there were no significant differences among isolates $(P>0.59$ and $0.51)$ and species $(P>0.27$ and 0.19$)$ on southern pea and tomato, respectively. For watermelon, disease incidence differed significantly among isolates $(P=0.0163)$ and species. Disease incidence on plants inoculated with $X$. leucotricha and $A$. verrucaria was significantly lower than on plants inoculated with all other species, except $G$. humicola isolate 29, which was not significantly different from any other isolate used. There was no significant difference between the two isolates of $G$. humicola. There were significant differences among hosts for the number of affected plant parts $(P<0.0001)$ but no host-isolate interaction $(P>0.49)$. Significantly more plant parts were

Table 3. Differences in average susceptibility among three host plant species inoculated with five species of Stachybotriaceae ${ }^{\mathrm{z}}$

\begin{tabular}{llllll}
\hline & \multicolumn{2}{c}{ Incidence } & & \multicolumn{2}{c}{$\begin{array}{c}\text { Number of affected } \\
\text { plant parts }\end{array}$} \\
\cline { 2 - 3 } \cline { 6 - 6 } Host & Mean & SE & & Mean & SE \\
\hline Southern pea & $0.12 \mathrm{~b}$ & 0.06 & & $0.26 \mathrm{c}$ & 0.11 \\
Tomato & $0.60 \mathrm{a}$ & 0.15 & & $1.80 \mathrm{a}$ & 0.66 \\
Watermelon & $0.55 \mathrm{a}$ & 0.15 & & $1.34 \mathrm{~b}$ & 0.49 \\
\hline
\end{tabular}

${ }^{\mathrm{z}}$ Means are proportions calculated across four experiments for incidence ratings and three experiments for the number of affected plant parts. Mean separation is based on differences of least squares means $(P<0.0001)$. Means within a column with the same letter are not significantly different. SE = standard error of least squares means calculated in SAS PROC GLIMMIX. affected on tomato than on southern pea and watermelon, and more plant parts were affected on watermelon than on southern pea (Table 3).

When hosts were analyzed separately, there was a significant host-isolate interaction for number of lesions per plant $(P<$ 0.0001) (Table 4). On southern pea, G. humicola isolate 92 caused significantly more lesions per plant than all other isolates except $A$. verrucaria and $P$. foliicola. $G$. humicola isolate 29 caused the lowest number of lesions per plant, which was significantly lower than all other isolates except $P$. humicola and $X$. leucotricha. On tomato, $P$. foliicola caused by far the highest number of lesions per plant, which was significantly higher than numbers caused by all other isolates. A. verrucaria caused the second highest number of lesions per tomato plant and differed significantly from all other isolates. As on southern pea, G. humicola isolate 29 caused the lowest number of lesions per plant, which was significantly lower than all other isolates. The remaining three isolates (G. humicola isolate 92, P. humicola, and $X$. leucotricha) grouped together with the second lowest number of lesions caused per plant and were statistically different from all other isolates. On watermelon, G. humicola isolate 92 and $P$. foliicola caused significantly more lesions than any other isolates. $X$. leucotricha caused the lowest number of lesions, significantly fewer lesions per plant than all other isolates. The other three isolates $(A$. verrucaria, G. humicola isolate 29 , and $P$. humicola) grouped together, causing the second highest numbers of lesions per plant (Table 4).

On southern pea, there were no significant differences among isolates with regards to diseased plant parts $(P>0.49)$. On tomato and watermelon, the differences were similar to what was observed for lesions per plant (data not shown).

There was a significant host-isolate interaction for disease severity $(P<0.0001)$ and there were significant differences among isolates for all three hosts. On southern pea, symptoms caused by A. verrucaria were significantly more severe than those caused by all other isolates, except for $G$. humicola isolate 92 and $P$. foliicola, which grouped together. G. humicola isolate 29 caused significantly less severe symptoms than those caused by any other isolate except $P$. humicola. The most severe symptoms on tomato were caused by $P$. foliicola, significantly more severe than those caused by all other isolates except $A$. verrucaria. Symptoms caused by both isolates of $G$. humicola were significantly less severe than symptoms caused by all other isolates but the severity of symptoms caused by G. humicola isolate 92 was statistically equal to that caused by $P$. humicola and $X$. leucotricha. On watermelon, $X$. leucotrich a caused the highest disease severity. It was significantly higher than the disease severity caused by all other isolates except $G$. humicola isolate 92 and $P$. foliicola. Symptoms caused by A. verrucaria were the least severe and significantly different from those caused by all other isolates, with the exception of $G$. humicola isolate 29 .

\section{Discussion}

In this study, we identified Stachybotriaceae species causing leaf lesions on cucurbits, especially watermelon, in South Carolina and characterized their morphology and pathogenicity. Here, we identified six species-A. verrucaria, $G$. humicola, $P$. foliicola, $P$. humicola, X. tongaense, and X. leucotricha-isolated from watermelon and two other cucurbits and confirmed their pathogenicity on southern pea, tomato, and watermelon. To the best of our knowledge, this is the first reliable report of pathogenicity of all six species on these three vegetable crops. A. verrucaria was reported on watermelon in India but the identification was based solely on morphology and, therefore, is questionable (Bharath et al. 2006). A. verrucaria and $P$. foliicola were recently found to cause leaf spot diseases on leafy vegetables and ornamental crops (Matić et al. 2019). Like the majority of cultures used by Lombard et al. (2016), all reference cultures of the species identified in this study were recovered from soil or air, except reference cultures of $A$. verrucaria and $X$. tongaense isolated from various plant tissues. Pathogenicity on plants of any kind has never been reported for $G$. humicola and P. humicola (Farr and Rossman 2018). Based on the present study and the findings of Matic et al. (2019), the previous ecological concept of Myrothecium-like fungi as mostly soilborne fungi with saprobic lifestyles deserves 
reconsideration (Lombard et al. 2016). The species most frequently isolated from watermelon were $G$. humicola followed by $P$. foliicola which, together, made up more than $85 \%$ of the isolates we identified. The other four species (A. verrucaria, P. humicola, X. leucotricha, and $X$. tongaense) occurred at very low levels.

Our finding of predominantly G. humicola and $P$. foliicola is in contrast to previous reports that identified $P$. roridum as the sole causal species of crater rot and Myrothecium leaf spot on cucurbits (Bruton and Fish 2012, 2017; Seebold et al. 2005). There are two main reasons for this myth. First, prior to the study by Lombard et al. (2016), which rearranged the family Stachybotriaceae, there was a lack of knowledge about the immense genetic diversity and species abundance in this family, despite a 2008 study based on ITS that showed that the genus Myrothecium was paraphyletic (Decock et al. 2008). Second, identification of pathogens based solely on morphology was widespread until the late 2000s and, to this day, identification is based mainly on the ITS region alone (Hibbett et al. 2007, Hyde et al. 2010, Raja et al. 2017). Although ITS is a useful tool for quick and general taxonomic classifications, there are many examples of species-rich genera with narrow or no barcode gaps, which show that ITS is unreliable and insufficient for identification to species level (Raja et al. 2017). Although Lombard et al. (2016) identified several distinct phenotypic characteristics they found suitable to distinguish Myrothecium-like fungal genera, morphological features appear unreliable for differentiation of genera in this group of fungi. The characteristics of many genera described by Lombard et al. (2016) are based merely on one or two isolates (e.g., Gregatothecium, Neomyrothecium, and Xenomyrothecium), and many phenotypic characteristics are shared among them.

In addition to the three gene regions $(C A L, T U B$, and $R P B 2)$ previously identified as best suited to resolve genera and underlying species in family Stachybotriaceae, we used the standard fungal barcode region ITS to identify the species in our collection. Analyses of individual gene regions (data not shown) showed that partial gene sequences of the TUB2 gene region followed by $R P B 2$ provided the best resolution of genera and species with the highest statistical support. The ITS gene region yielded the least resolution combined with only low statistical support. Species within several genera (e.g., Albifimbria, Paramyrothecium, and Xepicula) could not be resolved with the ITS region alone. Lombard et al. (2016) reported very similar findings. Furthermore, three isolates could be identified only as members of the genus Paramyrothecium but did not cluster with any species described by Lombard et al. (2016) in analyses of the combined dataset or any of the individual gene regions. Use of additional gene regions might resolve the three isolates in Paramyrothecium to species level. Therefore, future studies and disease reports on fungal pathogens in the family Stachybotriaceae should include sequence information of at least one other gene region in addition to ITS, and sequences should be compared with reference sequences from Lombard et al. (2016) and this study.

The present study not only revealed at least six Myrothecium-like species of Stachybotriaceae that cause foliar diseases of watermelon but also substantial genetic variability within these species. In addition, this is the first study to report within-field genetic diversity of the family Stachybotriaceae at scales as small as the individual leaf. The majority of G. humicola and P. foliicola isolates appeared to be clonal, based on sequence data of the four gene regions used in this study. We also found only a low nucleotide diversity, which is expected for organisms that reproduce asexually (de Jonge et al. 2013). The use of more detailed polymorphic sequence data such as produced by microsatellite markers may have revealed a higher nucleotide diversity (Selkoe and Toonen 2006). Nonetheless, we found several genetic differences between adjacent sampling points, within the same sampling points, and even on individual leaves. The distribution of the different haplotypes we found clearly demonstrated that isolates collected from the same sampling point or from the same leaf are not necessarily clonal. Based on the pathogenicity of the isolates tested in this study, G. humicola and $P$. foliicola may have a competitive advantage over the other species; however, further research is needed to establish the background for differences in pathogenicity among species of Stachybotriaceae. No sexual morphs have been reported from the species found in this study (Lombard et al. 2016). In light of the lack of sexual recombination, the fine-scale genetic differences we detected seem striking, because it still remains unknown how asexually propagating fungi achieve genetic recombination in order to adapt to their environment (de Jonge et al. 2013).

In a previous study, we estimated the effect of crop rotation on the probability of pathogen occurrence on a watermelon crop in the subsequent growing season (Rennberger et al. 2019). In fall 2016, it was more likely for Myrothecium sensu lato to occur in fields previously cropped to tomato than in fields cropped to cucurbits or fallowed prior to the sampling season. The present study confirmed that tomato is a highly susceptible host for this group of pathogens, and it tended to be even more susceptible than watermelon. This finding explains the increased probability of occurrence for species of

Table 4. Pathogenicity measurements of six isolates representing five species of Stachybotriaceae analyzed by host ${ }^{\mathrm{z}}$

\begin{tabular}{|c|c|c|c|c|c|c|}
\hline \multirow[b]{2}{*}{ Host } & \multirow[b]{2}{*}{ Isolate } & \multirow[b]{2}{*}{ Species } & \multicolumn{2}{|c|}{ Lesions per plant } & \multicolumn{2}{|c|}{ Severity } \\
\hline & & & Mean & $\overline{\mathrm{SE}}$ & Mean & SE \\
\hline \multirow[t]{6}{*}{ Southern pea } & 94 & Albifimbria verrucaria & $0.45 \mathrm{abc}$ & 0.52 & $0.48 \mathrm{a}$ & 0.57 \\
\hline & 29 & Gregatothecium humicola & $0.06 \mathrm{~d}$ & 0.08 & $0.07 \mathrm{~d}$ & 0.09 \\
\hline & 92 & G. humicola & $0.78 \mathrm{a}$ & 0.89 & $0.28 \mathrm{ab}$ & 0.33 \\
\hline & 77 & Paramyrothecium foliicola & $0.51 \mathrm{ab}$ & 0.59 & $0.37 \mathrm{ab}$ & 0.44 \\
\hline & 4 & P. humicola & $0.19 \mathrm{~cd}$ & 0.23 & $0.13 \mathrm{~cd}$ & 0.15 \\
\hline & 2 & Xepicula leucotricha & $0.25 \mathrm{bcd}$ & 0.30 & $0.20 \mathrm{bc}$ & 0.24 \\
\hline \multirow[t]{6}{*}{ Tomato } & 94 & A. verrucaria & $5.35 \mathrm{~B}$ & 4.94 & $3.94 \mathrm{AB}$ & 2.13 \\
\hline & 29 & G. humicola & $2.72 \mathrm{D}$ & 2.52 & $1.86 \mathrm{D}$ & 1.02 \\
\hline & 92 & G. humicola & $3.75 \mathrm{C}$ & 3.47 & $2.40 \mathrm{CD}$ & 1.30 \\
\hline & 77 & P. foliicola & $7.33 \mathrm{~A}$ & 6.77 & $4.37 \mathrm{~A}$ & 2.35 \\
\hline & 4 & P. humicola & $3.97 \mathrm{C}$ & 3.67 & $2.68 \mathrm{C}$ & 1.46 \\
\hline & 2 & $X$. leucotricha & $3.98 \mathrm{C}$ & 3.68 & $3.21 \mathrm{BC}$ & 1.74 \\
\hline \multirow[t]{6}{*}{ Watermelon } & 94 & A. verrucaria & $2.72 \mathrm{~b}$ & 1.05 & $1.59 \mathrm{c}$ & 1.25 \\
\hline & 29 & G. humicola & $2.77 \mathrm{~b}$ & 1.09 & $2.18 \mathrm{bc}$ & 1.71 \\
\hline & 92 & G. humicola & $5.52 \mathrm{a}$ & 2.07 & $2.60 \mathrm{ab}$ & 2.04 \\
\hline & 77 & P. foliicola & $5.82 \mathrm{a}$ & 2.17 & $2.61 \mathrm{ab}$ & 2.04 \\
\hline & 4 & P. humicola & $3.39 \mathrm{~b}$ & 1.30 & $2.26 \mathrm{~b}$ & 1.77 \\
\hline & 2 & X. leucotricha & $1.45 \mathrm{c}$ & 0.62 & $3.21 \mathrm{a}$ & 2.51 \\
\hline
\end{tabular}

${ }^{\mathrm{z}}$ Means were calculated across three experiments for lesions per plant and four experiments for severity ratings. Data are presented by host due to a significant host-isolate interaction for both measurements $(P<0.0001)$. Mean separation within a host is based on differences of least squares means $(P \leq 0.05)$. Means within columns of hosts with the same letter are not significantly different. SE $=$ standard error of least squares means calculated in SAS PROC GLIMMIX 
Stachybotriaceae following a tomato crop. The collection of isolates for this study was started when Myrothecium sensu lato was first found on leaves of watermelon during the sampling for Rennberger et al. (2018) in July 2015. After the first finding, all fields sampled for Rennberger et al. (2018) were concomitantly monitored for additional isolates of Myrothecium sensu lato. It is not clear why we were unable to obtain more isolates in 2015 and 2016 and from counties other than Beaufort County. All four fields sampled in September 2017 in Beaufort County, from which we collected the majority of the isolates used in this study, were cropped to tomato in both spring 2017 and spring 2016. Based on our findings of high susceptibility of tomato to this group of pathogens, it appears likely that the crop rotation rich in tomato and watermelon in Beaufort County led to an increase of species of Stachybotriaceae in the watermelon fields we sampled in September 2017. Bruton and Fish (2012) reported a history of more than 15 years of continuous cucurbit production in a field in Oklahoma as a major reason for an outbreak of Myrothecium leaf spot. Under humid conditions in areas with previous reports of the disease, we recommend avoiding crop rotations that include both cucurbits and solanaceous crops. In addition, Corynespora cassiicola, another pathogen shared by watermelon and tomato, was found frequently in the fields sampled in September 2017, which is another indication for a strong effect of crop rotation on the occurrence of foliar pathogens of watermelon (Rennberger et al. 2018, 2019).

$P$. foliicola and $G$. humicola were consistently among the most virulent species in our pathogenicity tests. The higher virulence of these two species could be a reason for their predominance among the isolates collected for this study. The species that were found only at low frequencies (A. verrucaria, P. humicola, and X. leucotricha) were generally less virulent on watermelon, which could explain their low occurrence in the fields we sampled. However, the pathogenicity tests also revealed variability of virulence between the two isolates of $G$. humicola that were included. In greenhouse pathogenicity tests in Texas, Carter (1980) also reported significant differences in virulence among 15 isolates obtained from symptomatic watermelon fruit, leaves, and stems. In systems where infections are frequent, and a host is shared by nonrelated parasites, virulence is expected to increase, because pathogens able to exploit host resources at a higher rate outcompete less virulent pathogens (van Baalen and Sabelis 1995; López-Villavicencio et al. 2007). These factors might play a role in the prevalence of $G$. humicola and $P$. foliicola in watermelon fields in South Carolina.

A combination of up to five different fungicide active ingredients with Fungicide Resistance Action Committee Codes M, 1, 3, 7, 9, 11 , and 12 was applied to watermelon fields within 1 week of sampling in September 2016 and 2017 (Rennberger et al. 2018). This suggests no clear effect of the applied fungicides in controlling the species of Stachybotriaceae found in the sampled fields. It is interesting to note that mancozeb was applied to two fields 2 weeks prior to sampling in 2017 but no mancozeb was used within 1 week of sampling. Carter (1980) found that a mixture of benomyl and zinc ion-maneb (a formulation of mancozeb) effectively controlled leaf lesions and stem cankers caused by Myrothecium sensu lato. He presumed that primary infections occurred before the first bloom, because a single fungicide application at flower onset was sufficient to control the disease (Carter 1980). Further studies are needed to determine fungicides with high efficacy against this group of pathogens, as well as to discover potential differential fungicide sensitivities among the different species and isolates.

Due to the lack of a common name for foliar symptoms of diseases caused by any members of the family Stachybotriaceae that we found in this study, we propose the common name "ink spot" for the foliar phase of diseases caused by this group of pathogens. This name is descriptive, likely to be accepted by growers, and would facilitate monitoring, reporting, and discussing foliar diseases caused by any species within the Stachybotriaceae family. This study is the first report of pathogenicity of A. verrucaria, G. humicola, P. foliicola, $P$. humicola, $X$. leucotricha, and $X$. tongaense on watermelon, tomato, and southern pea. Ink spot diseases of cucurbits caused by these species appear to be increasing in frequency in South Carolina and should be monitored in the future, especially in crops grown under humid fall conditions. Further research is needed to establish suitable management practices.

\section{Acknowledgments}

We thank W. P. Wechter, M. L. Katawczik, M. S. Caterino, and S. M. Toporek for advice with molecular analyses; P. D. Gerard for statistical advice; and the South Carolina Agricultural Society for supplying the Thomas Heyward Jr. Graduate Fellowship to G. Rennberger.

\section{Literature Cited}

Ali, S., Murtaza, A. W. M., and Nadeem, A. 1988. Myrothecium leaf spot of bittergourd in Pakistan. Pak. J. Agric. Res. 9:598-600.

Bharath, B. G., Lokesh, S., Raghavendra, V. B., Prakash, H. S., and Shetty, H. S 2006. First report of the occurrence of Myrothecium verrucaria in watermelon seeds from India. Australas. Plant Dis. Notes 1:3-4.

Brooks, S. P., and Gelman, A. 1998. General methods for monitoring convergence of iterative simulations. J. Comput. Graph. Stat. 7:434-455.

Bruton, B. D., and Fish, W. W. 2012. Myrothecium roridum leaf spot and stem canker on watermelon in the southern Great Plains: Possible factors for its outbreak. Plant Health Prog. 13.

Bruton, B. D., and Fish, W. W. 2017. Crater rot. Pages 94-96 in: Compendium of Cucurbit Diseases and Pests, 2nd ed. A. P. Keinath, W. M. Wintermantel, and T. A. Zitter, eds. American Phytopathological Society, St. Paul, MN, U.S.A.

Cabral, C. S., Henz, G. P., Moreira, A. J. A., and Reis, A. 2009. New cucurbitaceous hosts of Myrothecium roridum in Amazonas State, Brazil. Trop. Plant Pathol. 34:402-405.

Carbone, I., and Kohn, L. M. 1999. A method for designing primer sets for speciation studies in filamentous ascomycetes. Mycologia 91:553-556.

Carter, W. W. 1980. Incidence and control of Myrothecium roridum on cantaloupe in relation to time of fungicide application. Plant Dis. 64:872-874.

Chen, Z.-D., Li, P.-L., Chai, A.-L., Guo, W.-T., Shi, Y.-X., Xie, X.-W., and Li, B.-J. 2018. Crown canker caused by Paramyrothecium roridum on greenhouse muskmelon (Cucumis melo) in China. Can. J. Plant Pathol. 40:115-120.

Darriba, D., Taboada, G. L., Doallo, R., and Posada, D. 2012. jModelTest 2: More models, new heuristics and parallel computing. Nat. Methods 9:772.

Decock, C., Huret, S., and Bivort, C. 2008. Anamorphic fungi from French Guyana. Septomyrothecium sp. nov. and S. setiramosum comb. nov. (anamorphic Hypocreales, Ascomycota). Cryptogam. Mycol. 29:321-331.

de Jonge, R., Bolton, M. D., Kombrink, A., van den Berg, G. C. M., Yadeta, K. A., and Thomma, B. P. H. J. 2013. Extensive chromosomal reshuffling drives evolution of virulence in an asexual pathogen. Genome Res. 23:1271-1282.

Farr, D. F., and Rossman, A. Y. 2018. Fungal Databases. U.S. National Fungus Collections, United States Department of Agriculture-Agricultural Research Service. https://nt.ars-grin.gov/fungaldatabases/

Glass, N. L., and Donaldson, G. 1995. Development of primer sets designed for use with PCR to amplify conserved genes from filamentous ascomycetes. Appl. Environ. Microbiol. 61:1323-1330.

Groenewald, J. Z., Nakashima, C., Nishikawa, J., Shin, H.-D., Park, J.-H., Groenewald, M., Braun, U., and Crous, P. W. 2013. Species concepts in Cercospora: Spotting the weeds among the roses. Stud. Mycol. 75:115-170.

Hibbett, D. S., Binder, M., Bischoff, J. F., Blackwell, M., Cannon, P. F., Eriksson, O. E., Huhndorf, S., James, T., Kirk, P. M., Lucking, R., Lumbsch, H. T., Lutzoni, F., Matheny, P. B., McLaughlin, D. J., Powell, M. J., Redhead, S., Schoch, C. L., Spatafora, J. W., Stalpers, J. A., Vilgalys, R., Aime, M. C., Aptroot, A., Bauer, R., Begerow, D., Benny, G. L., Castlebury, L. A., Crous, P. W., Dai, Y. C., Gams, W., Geiser, D. M., Griffith, G. W., Gueidan, C., Hawksworth, D. L., Hestmark, G., Hosaka, K., Humber, R. A., Hyde, K. D., Ironside, J. E., Koljalg, U., Kurtzman, C. P., Larsson, K. H., Lichtwardt, R., Longcore, J., Miadlikowska, J., Miller, A., Monclavo, J. M., MozleyStanridge, S., Oberwinkler, F., Parmasto, E., Reeb, V., Rogers, J. D., Roux, C., Ryvarden, L., Sampaio, J. P., Schussler, A., Sugiyama, J., Thorn, R. G., Tibell, L., Untereiner, W. A., Walker, C., Wang, Z., Weir, A., Weiss, M., White, M. M., Winka, K., Yao, Y.-J., and Zhang, N. 2007. A higher level phylogenetic classification of the Fungi. Mycol. Res. 111:509-547.

Huelsenbeck, J. P., and Rannala, B. 2004. Frequentist properties of Bayesian posterior probabilities of phylogenetic trees under simple and complex substitution models. Syst. Biol. 53:904-913.

Hyde, K. D., Abd-Elsalam, K., and Cai, L. 2010. Morphology: Still essential in a molecular world. Mycotaxon 114:439-451.

Katoh, K., and Standley, D. M. 2013. MAFFT multiple sequence alignment software version 7: Improvements in performance and usability. Mol. Biol. Evol. 30:772-780.

Keinath, A. P. 2008. Survival of Didymella bryoniae in infested muskmelon crowns in South Carolina. Plant Dis. 92:1223-1228.

Lecocq, T., Vereecken, N. J., Michez, D., Dellicour, S., Lhomme, P., Valterova, I., Rasplus, J.-Y., and Rasmont, P. 2013. Patterns of genetic and reproductive traits differentiation in mainland vs. Corsican populations of bumblebees. PLoS One 8:e65642.

Lombard, L., Houbraken, J., Decock, C., Samson, R. A., Meijer, M., Réblová, M., Groenewald, J. Z., and Crous, P. W. 2016. Generic hyper-diversity in Stachybotriaceae. Persoonia 36:156-246. 
López-Villavicencio, M., Jonot, O., Coantic, A., Hood, M. E., Enjalbert, J., and Giraud, T. 2007. Multiple infections by the anther smut pathogen are frequent and involve related strains. PLoS Pathog. 3:e176.

Matić, S., Gilardi, G., Gullino, M. L., and Garibaldi, A. 2019. Emergence of leaf spot disease on leafy vegetable and ornamental crops caused by Paramyrothecium and Albifimbria species. Phytopathology 109:1053-1061.

McLean, D. M., and Sleeth, B. 1961. Myrothecium rind rot of cantaloupe. Plant Dis. Rep. 45:728-729.

Miller, M. A., Pfeiffer, W., and Schwartz, T. 2010. Creating the CIPRES Science Gateway for inference of large phylogenetic trees. Pages 1-8 in: Proc. Gateway Comput. Environ. Workshop (GCE), 14 November 2010, New Orleans, LA, U.S.A.

Nag Raj, T. R. 1993. Coelomyceous Anamorphs with Appendage-Bearing Conidia. Mycologue Publications, Waterloo, Ontario, Canada.

Nei, M., and Tajima, F. 1983. Maximum likelihood estimation of the number of nucleotide substitutions from restriction sites data. Genetics 105:207-217.

O’Donnell, K., Sarver, B. A., Brandt, M., Chang, D. C., Noble-Wang, J., Park, B. J., Sutton, D. A., Benjamin, L., Lindsey, M., Padhye, A., Geiser, D. M., and Ward, T. J. 2007. Phylogenetic diversity and microsphere array-based genotyping of human pathogenic Fusaria, including isolates from the multistate contact lens-associated U.S. keratitis outbreaks of 2005 and 2006. J. Clin. Microbiol. 45:2235-2248

Raja, H. A., Miller, A. N., Pearce, C. J., and Oberlies, N. H. 2017. Fungal identification using molecular tools: A primer for the natural products research community. J. Nat. Prod. 80:756-770.

Rennberger, G., Gerard, P., and Keinath, A. P. 2018. Occurrence of foliar pathogens of watermelon on commercial farms in South Carolina estimated with stratified cluster sampling. Plant Dis. 102:2285-2295.
Rennberger, G., Gerard, P., and Keinath, A. P. 2019. Factors influencing the occurrence of foliar pathogens in commercial watermelon fields in South Carolina based on stratified cluster sampling. Plant Dis. 103:484-494.

Rozas, J. 2009. DNA sequence polymorphism analysis using DnaSP. Methods Mol. Biol. 537:337-350.

Rozas, J., and Rozas, R. 1997. DnaSP version 2.0: A novel software package for extensive molecular population genetics analysis. Comput. Appl. Biosci. 13: 307-311.

Schoch, C. L., Seifert, K. A., Huhndorf, S., Robert, V., Spouge, J. L., Levesque, C. A., and Chen, W., and Fungal Barcoding Consortium. 2012. Nuclear ribosomal internal transcribed spacer (ITS) region as a universal DNA barcode marker for fungi. Proc. Natl. Acad. Sci. U.S.A. 109:6241-6246.

Seebold, K. W., Jr., Langston, D. B., Jr., Kemerait, R. C., Jr., and Hudgins, J. E. 2005. First report of a leaf spot and stem canker caused by Myrothecium roridum on watermelon in the United States. Plant Dis. 89:342.

Selkoe, K. A., and Toonen, R. J. 2006. Microsatellites for ecologists: A practical guide to using and evaluating microsatellite markers. Ecol. Lett. 9:615-629.

Tulloch, M. 1972. The genus Myrothecium Tode ex Fr. Mycol. Pap. 130:1-44.

van Baalen, M., and Sabelis, M. W. 1995. The dynamics of multiple infection and the evolution of virulence. Am. Nat. 146:881-910.

White, T. J., Bruns, T., Lee, S., and Taylor, J. 1990. Amplification and direct sequencing of fungal ribosomal RNA genes for phylogenetics. Pages 315-322 in: PCR Protocols: A Guide to Methods and Applications. M. A Innis, D. H. Gelfand, J. J. Shinsky, and T. J. White, eds. Academic Press, San Diego, CA, U.S.A.

Yang, S.-M., and Jong, S. C. 1995. Host range determination of Myrothecium verrucaria isolated from leafy spurge. Plant Dis. 79:994-997. 